\title{
AN EFFICIENT APPROACH FOR SELECTIVE COLLECTION MADE BY SCAVENGERS FOR TRANSPORTATION LOGISTICS OF RECYCLABLE MATERIALS
}

\author{
Adelino Carlos Maccarini \\ Universidade Tecnológica Federal do Paraná (UTFPR), Brazil \\ E-mail: maccarini@utfpr.edu.br \\ Gilson Adamczuk Oliveira \\ Universidade Tecnológica Federal do Paraná (UTFPR), Brazil \\ E-mail: gilson@utfpr.edu.br
}

Naiá Mendes Maccarini Universidade Tecnológica Federal do Paraná (UTFPR), Brazil E-mail: naia.mac@gmail.com

João Bosco Ladislau de Andrade Universidade Tecnológica Federal do Paraná (UTFPR), Brazil E-mail: boscoladislau@mandic.com.br

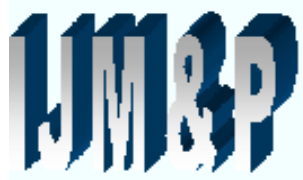

\section{ABSTRACT}

Submission: $30 / 04 / 2013$

Revision: 16/05/2013

Accept: 10/10/2013

The advance of technology, associated to the increase in the production of recyclable waste due to the increase of consumption and population, has been led to a search for alternatives of management and minimization of this waste. A part of this recyclable material is collected by scavengers, who do it to guarantee their livelihood. Many of them face logistical difficulties in transportation, mainly when they have to walk long distances and the streets have high slopes.

Therefore, to minimize these efforts, the purpose of this paper is to settle mobile warehouses to receive recyclable items, with trucks that receive in bulk all materials collected by the collectors, who will deliver them to someone who will be in the truck for weighing and subsequent payment to the collector. With the help of the Analysis of Variance ANOVA, studies were made so that this receipt is a quick operation, with the historical record of each sampling in a spreadsheet and value calculations based on this description, thus minimizing errors in weighing in bulk and improving, in every collection, the system reliability. 
DOI: 10.14807/ijmp.v5i1.80

Keywords: selective collection, scavengers, waste material picks, collector, solid waste, garbage, ANOVA, statistical methods.

\section{INTRODUCTION}

The selective collection made by scavengers has been structured each day. Methods to minimize the effort often arise, but the collectors still face serious logistical difficulties in transporting recyclable materials, especially when they have to travel long distances and higher slopes streets.

Some methods are uneconomical, with high and inaccessible costs to the collectors' reality. An example is the installation of fixed warehouses, scattered throughout the city, for delivery and commercialization of recyclable materials. Beyond expensive, can cause discomfort to the surrounding residents because of outbreaks of dirt and odors, also proliferation of vectors such as rats, cockroaches and flies. If these fixed warehouses were managed by collectors, the surrounding community, in a way, would further reject the initiative, because, among other problems, many residents, by distrust, do not accept the collectors.

The purpose of this study is to install up mobile warehouses, rather than fixed receiving warehouses, with trucks that receive, in bulk, all collected materials. The scavengers would deliver the materials to someone who would stay in the truck for weighing and subsequent payment to the collector. Using the Analysis of Variance method - ANOVA, proposed by Ronald Aylmer Fisher in 1925, this receipt should be a quick operation. With the historical record of each sampling in a spreadsheet and value calculations based on this description, it is possible reduce weighing time in bulk errors and improving, in every collection, the system reliability.

The aims of this research are: analyse the receipt processes of recyclable materials; relate the weighing of materials collected daily by the pickers with the historical of what was collected during a particular period; show that is possible reduce the time in material separation tasks, delivering in homogeneous groups formed through ANOVA; speeding up the materials weighing; propose a more efficient and faster way to commercialize recyclable materials.

\section{LITERATURE REVIEW}

Developing countries are faced with serious environmental and administrative challenges with respect to solid waste (SW) management. The public sanitation 
system lacks because of inadequate planning, as well as unsustainable management. Mexico, for example, depends heavily on personnel with no technical training and the separation of the waste is carried out by an ever-increasing number of scavengers. It is essential include these groups in the decision-making process in order to assure the success SW management programs (BUENROSTRO; BOCCO, 2003).

An important goal of a successful solid waste management program is to handle and dispose waste at a reasonable cost while minimizing adverse environmental effects. A well-planned recycling program may help achieve this goal while also creating job opportunities and conserving material resources. Recycling and composting have been practiced advantageously in many cities of the developed countries (AGUNWAMBA, 2003).

Also it is relevant, mainly in developing countries, to reduce the amount of waste generated and sent to the open dumps. Recycling and reuse practices can make this possible. It is also very necessary to improve and help organize markets for the recyclables. Information and education can bring a change to people's towards waste management, and it can encourage the public attitudes to take responsibility for the waste generated (BATOOI; NAWAZ, 2009).

As in other major cities in developing countries, the informal sectors still hold an important role in the recovery of usable materials from waste. However, inorganic waste recycling activities from this sector have not even reached $8 \%$ (wet weight) of the total waste generated (DAMANHURI et al., 2009). Batool et al. (2008) suggest if the recycling practice is owned by the formal sector, it can save substantial economic amounts by reducing the collection cost. If recycling is adopted as an industry, it can generate more revenues and can also save an enormous amount of energy, as well as the natural resources. It indicates how the informal sector (the autonomous scavengers) has a high field to advance to justify its future in this important activity.

According Kimbugwe \& Ibitayo (2013) there is an indication that the scavengers do not consider waste picking as transitory, but as a full time and stable form of employment. Scavengers are poor people, suffer harassment from officials and face health and safety problems during the work. Despite of their low economic and social status, the overall impact of activities of scavengers is positive economically and environmentally. This can be improved further if the government or 
organized private sector helps them by organizing them, providing them medical and health facilities, personal protective equipment and financial incentives (ASIM et al., 2012).

Despite the innumerous social, economic, and environmental benefits from resource recovery activity made by scavengers, it is still illegal in most places, as it is also in Canada (GUTBERLET; JAYME, 2010). It may contribute to explain discrimination against individuals who deal with selective collection of recyclables and decrease the value of their work.

Porto Alegre, a 1.5-million city, has one of the most affordable integrated solid waste management systems in Brazil. Public participation as a part of the integrated solid waste management system has been established by allocating a participatory budget, involving former scavengers associations and implementing an environmental education programme. It has led to a reduction in the quantity of solid waste deposited in landfill, allowing income generation for the scavengers, as a way to decrease local poverty (BORTOLETO; HANAKI, 2007).

According to Cempre (2007), Brazil produces around 140,000 tons of waste per day. A portion of this waste, around $90 \%$, goes to dumps or landfills, and only $10 \%$ is sent for recycling or composting. A great part of the considered good material has been gone to waste and a lot of money has been thrown away, mainly due to not reusing the materials, how complements Calderoni (1998).

The generation of waste in urban areas depends on some factors, which are important, among others, in the assessment of some issues regarding to solid waste, described by Andrade (1989). They are: economic, environmental, sanitary, community, cultural, political, number of local inhabitants and city expansion, usual types of packaging, collections types and collection equipment types, road system and flooring routes types, distance to final destination and appropriate way to final destination, the relative area of production, discipline and control of the producers points, seasonal variations; climatic conditions; habits; educational level; segregation at source; systematization of origin, specific laws and regulations.

The number of scavengers existing in Brazil is very controversial. MNCR (2007) mentions that there are between 500 thousand and one million of scavengers. This model suffers variations in each region of the country, due to the country size 
DOI: 10.14807/ijmp.v5i1.80

and diversity, where the activity is governed by the market laws. What contributes to the support of the process itself and create working conditions for those unemployed or those without employment expectation.

The scavengers are also known as collectors, pickers, paper gatherer, rag picker, trash collectors, unofficial waste sorters/recyclers, trash scavengers, waste material pickers, litter-pickers, litter collector and others, according Gutberlet et al. (2009). Maccarini and Hernandez (2007) divided the activity into three primary classifications: the scavenger, who lives in the dumps collecting recyclable materials and then sell them to intermediaries; those who collect on the streets with their carts, wagons or other vehicles (Figure 1) and are often called "paper gatherer" and also negotiate their materials with intermediaries; and those who work in sorting recyclable materials centres and are often linked to a cooperative or association.

Hence the selective collection made by the scavengers is, according National Movement of recyclables scavengers from Brazil (MNCR, 2007), a new model to perform the selective collection. Preferably consists of, instead of the municipal agency collect the selected material, the collectors, duly registered and organized, would do it.

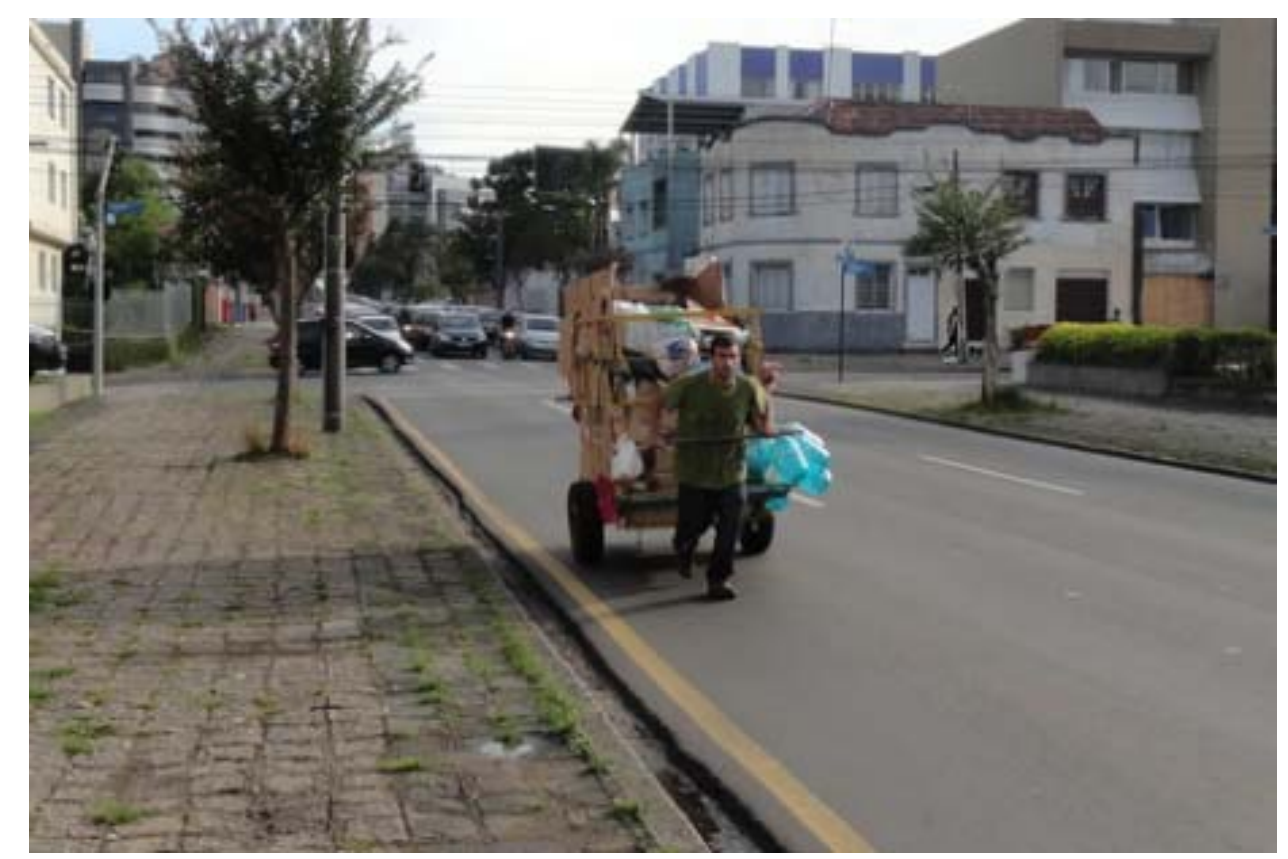

Figure 1 - Scavenger with his trolley, collecting on the streets

According Eigenheer (1989), scavengers usually live in suburbs or slums and collect materials at random in the streets of the districts and commercial centres of the cities. Most of them are semi-literate and are not organized in associations as 
stated by Cempre/Eurostat (2006). Due to their lifestyle, for realizing an activity which is not professionally recognized, many are marginalized and discriminated by society. Some often get involved in police incidents, due to alcohol ingestion and similar, like Folha de São Paulo newspaper (2006) reports.

\section{MATERIALS AND METHODS}

\subsection{Recyclable characterization and statistical analysis}

The following is a brief description of recyclable characterization and statistical analysis. Costa Neto (1989) says that, since the product is formed by solid material if the homogenization is not feasible, such as the recyclable materials in this study, it is possible to apply the quartering as called by Tchobanoglous (1993). This method recommends the division of the material to be characterized in four parts, sorting one or more parts to constitute a sample or removing a sample from them.

Toledo \& Ovalle (1988) recommend, after obtaining these data for the characterization, the use of simple arithmetic average of relative quantity $\left(\bar{q}_{0, t}\right)$ defined by:

$$
\bar{q}_{0, t}=\frac{\sum_{i=1}^{n} q_{0, t}^{i}}{n}
$$

Where:

$\bar{q}_{0, t}=$ simple arithmetic average of relative quantity;

$q_{0, t}^{i}=$ amount of these materials at the present time and basic zero;

$\mathrm{n}=$ number of samples.

For the selective collection, there are various possibilities for statistical calculations, such as proposed by Hines (2006). Therefore, to increase the reliability of data collected and minimize errors, like Stevenson (1986) says, it is necessary, first of all, defined its purpose: how, where and what is the intended information. Also, mentions the author that is also relevant to recognize, measure and understand the causes of variability, to act about them and then, the results should be measured and interpreted from technical and scientific measures. Complement Shimazaki 
(2007) that these measures start with simple methods, such as the arithmetic mean, and advance in extremely complex calculations, now aided by computer technology.

Statistical surveys may assist the work of scavengers logistics, but due to a lack of adequate procedures and technical support, was noticed the difficulty in putting into practice. To apply the results collected on this work, any error made in the evaluation of the selective materials collected percentage may mainly affect he collector, who lives on sparing resources. If, however, there is any error of judgment in favor of the collector, who will suffer are those who will make the purchase of materials, in this study, the association or cooperative of scavengers.

The simple and usual ANOVA hypothesis test was applied. According to Caten (2007), it essentially divides the variability between groups and within groups and compares both. This feature allows realizing a simple variance analysis for two factors with only one sample per group. ANOVA is used to determine if the means of two or more samples are from the same population. In this case are formed groups of recyclable materials that have the same relative amount.

\subsection{Statistical method applied to the selective collection made by scavengers}

The simple and usual ANOVA hypothesis test was applied. The independent variable is composed by the 12 groups of recyclable materials and the dependent variable is the percentage of collected recyclables.

\subsection{Bulk weighing method}

The installation of fixed warehouses, scattered throughout the city, for the delivery and commercialization of recyclable materials collected by scavengers, beyond costly, would result, according to Maccarini studies (2007), discomfort to surrounding residents. Besides, it could cause dirt and odors outbreaks, with the proliferation of vectors such as rats, cockroaches, flies, among others. Besides, what the society has not accepted much, is the agglomeration of collectors in their neighbourhood. Another procedure to be performed could be the one with which the collector performs triage in loco in their own stand. However the space is small to accomplish this separation, which makes also this procedure unfeasible. The distances, that usually are long to transport the trolley to the store, are also determinant factors to new thoughts about alternatives. 
DOI: 10.14807/ijmp.v5i1.80

One of these alternatives is that, instead of creating fixed warehouses to receiving material, settle them in mobile ones. These warehouses would be formed by a truck and receivers strategically located in the neighbourhood, at points near the collection sites.

For the realization of this method, should be implemented before the model of selective collection made by scavengers proposed by Maccarini (1998). This model involves the participation of the local community who should leave the separated garbage in front of their houses, on determined days of the week. The pickers can then start collecting, and, so that, as soon as they fill the stands, take to these mobile centres of receiving recyclable materials.

The receivers would weigh the bulk of material from each collector, depositing them into bins within the mobile centres of receiving material (which may be a truck or similar) to then be transported to sorting centres with subsequent separation of each specific item. This procedure would tend to be fast, given that would not be needed a receiver or scavengers to make a detailed screening of the materials, to then know the quantity and what kind of materials were collected. This would provide the pickers return to stretch to make more collections than by the traditional method. Figure 2 illustrates the Bulk weighing method.

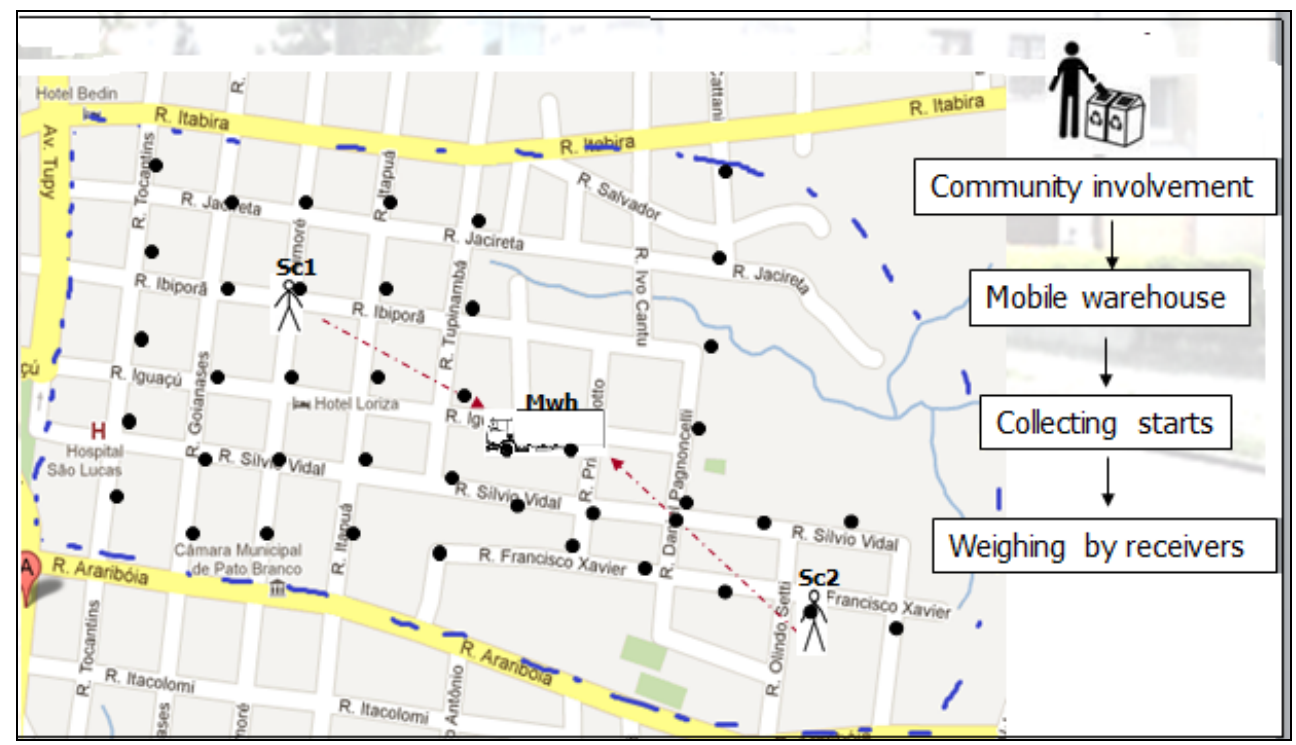

Figure 2 - Bulk weighing method: an illustrative example

In the sorting centres, the recyclable materials can generate more than 20 different types and which each one is sold with different prices. Some with higher value than the average of other materials (aluminium, for example, is sold at an 
average of $R \$ 2,00$ per kilogram, copper at $R \$ 7,00$, while other materials ranging from $R \$ 0,05$ to $R \$ 0,40$ per kilogram). To avoid future troubles, these materials with much higher values, above average, must first be separated, weighed and paid apart, because, in conformity with Downing \& Clark (2000), they have a large amplitude range.

To facilitate the study, in this paper the recyclable materials were divided into 12 items only: waste, newspapers, paper (white), cardboard, thin plastic, hard plastic, PET, glass, ferrous metals, aluminium, copper and similar, and others. The tailings are all that material which cannot be recycled and eventually appear on the collected materials, mainly due to lack of knowledge or education of who separates the trash at home. They include organic waste, toilet waste, pruning and weeding, among others, which should be directed to the ordinary or special domicile collection. The classified like papers, include all those white papers that were not dirty or contaminated by other residues. The thin plastic is particularly LDPE (low density polyethylene), such as the plastic bags. The hard plastics are HDPE (high density polyethylene), PP (polypropylene), PS (polystyrene), PVC (polyvinyl chloride), among others. PET (polyethylene terephthalate) is the plastic used in soda bottles and other containers. The glass comprises mainly canning containers and glass bottles. Ferrous metals are the "tin plate" and other ferrous metals. Copper and related products represent all non-ferrous metals except aluminum. The "others" are those which do not fit into any classification previously exposed, such as: rubber, furniture, electronics, clothes and rags, wood, among others.

\subsection{Survey samples}

Maccarini (1998) conducted studies and characterizations of recyclable materials collection performed by scavengers (Table 1 ). These studies provided 11 characterization data (11 samples) to be interpolated and used with other realized by Maccarini \& Hernandez (2007) (Table 2) and also by data collection performed by Maccarini (2008) (Table 3).

Thus, the collected information was grouped to form three distinct data groups. The first called "Group 1" is one whose data from 11 characterizations shown in Table 1. For practical purposes, even though these data were outdated, they were used in this study, mainly by having a large number of samples and detail level. Thus, the amount of information was increased enabling the results to be completed 
with the highest degree of reliability. Another reason for using these samples was because the percentages of some materials differ a little in relation to data collected by Maccarini \& Hernández (2007), which were also used as historical data. These were called "Group 2" (Table 2).

For more data and to make better comparisons with the existing, Maccarini (2008) made a new characterization from the materials found on a trolley collector, chosen at random, in the streets of Pato Branco city - PR. These materials were fully separated and weighed, item by item, as shown in Table. Thus, the total sum of the collected samples is 13 , forming the three groups for being studied.

Table 1 data are about a single district of the city and in one day of the week (Wednesday). Those raised in 2007 (Table 2) we extracted from a study by Maccarini \& Hernández (2007), in the shed of the Association of Scavengers. There, the materials were mixed and homogenized. Finally, those identified in Group 3 (Table 3) are about a day of the week (Thursday), without definition of a place of origin.

Table 1: Detailed characterizations, from the collections made by collectors MATERIA QUANTITY (\%)/ collected days (group 1) LS

\begin{tabular}{|c|c|c|c|c|c|c|c|c|c|c|c|c|c|}
\hline & \begin{tabular}{|l|}
1 st \\
collec \\
ts
\end{tabular} & $\begin{array}{l}\text { 2nd } \\
\text { collec } \\
\text { ts }\end{array}$ & \begin{tabular}{|l|} 
3rd \\
collect \\
s
\end{tabular} & \begin{tabular}{|l}
4 th \\
collec \\
ts
\end{tabular} & $\begin{array}{l}\text { 5th } \\
\text { colle } \\
\text { cts }\end{array}$ & \begin{tabular}{|l} 
th \\
collect \\
s
\end{tabular} & \begin{tabular}{|l}
7 th \\
collect \\
s
\end{tabular} & \begin{tabular}{|l|} 
8th \\
tcollect \\
s
\end{tabular} & $\begin{array}{l}9 \text { th } \\
\text { collec } \\
\text { ts }\end{array}$ & $\mid \begin{array}{l}10 \text { th } \\
\text { collect } \\
\mathrm{s}\end{array}$ & $\begin{array}{l}\text { 11th } \\
\text { collect } \\
\mathrm{s}\end{array}$ & average & $\begin{array}{l}\text { standaro } \\
\text { deviatio } \\
\text { n }\end{array}$ \\
\hline Reject & 11,6 & 19,2 & 1,9 & 1,6 & 2,4 & 3,8 & 3,5 & 1,4 & 7,1 & 1,1 & 3,1 & 4,43 & 5,59 \\
\hline $\begin{array}{l}\text { Newspape } \\
r\end{array}$ & 6,4 & 5,3 & 32,1 & 2,9 & 6,2 & 12,6 & 6,0 & 4,5 & 8,8 & 4,8 & 3,4 & 10,66 & 8,29 \\
\hline $\begin{array}{l}\text { White } \\
\text { paper }\end{array}$ & 8,6 & 7,7 & 6,4 & 13,9 & 20,3 & 10,0 & 10,5 & 10,6 & 23,8 & 21,5 & 10,4 & 11,86 & 6,01 \\
\hline Cardboard & 24,0 & 31,9 & 11,6 & 13,1 & 24,2 & 19,8 & 13,4 & 17,5 & 18,9 & 21,4 & 18,8 & 17,80 & 5,88 \\
\hline $\begin{array}{l}\text { Thin } \\
\text { plastic }\end{array}$ & 5,4 & 4,2 & 2,3 & 3,8 & 6,8 & 4,0 & 2,9 & 5,0 & 3,2 & 4,6 & 3,8 & 3,89 & 1,25 \\
\hline $\begin{array}{l}\text { Hard } \\
\text { plastic }\end{array}$ & 12,3 & 12,4 & 5,8 & 5,8 & 9,7 & 6,7 & 4,9 & 5,8 & 6,9 & 7,4 & 5,0 & 7,04 & 2,73 \\
\hline PET & 0,0 & 0,0 & 0,0 & 6,3 & 8,2 & 5,8 & 3,8 & 4,9 & 7,2 & 7,5 & 5,7 & 4,00 & 3,13 \\
\hline Glass & 25,8 & 14,8 & 12,9 & 21,9 & 10,4 & 22,6 & 47,8 & 37,8 & 14,2 & 19,7 & 26,3 & 23,38 & 11,27 \\
\hline $\begin{array}{l}\text { Ferrous } \\
\text { metal }\end{array}$ & 3,3 & 3,8 & 7,1 & 24,6 & 8,6 & 8,7 & 3,7 & 6,5 & 4,6 & 6,3 & 10,1 & 8,75 & 5,97 \\
\hline Aluminum & 1,4 & 0,7 & 1,3 & 0,5 & 2,0 & 1,5 & 1,7 & 0,9 & 1,0 & 1,1 & 0,9 & 1,17 & 0,45 \\
\hline $\begin{array}{l}\text { Copper } \\
\text { and } \\
\text { related }\end{array}$ & 0,0 & 0,0 & 1,1 & 0,0 & 0,0 & 0,0 & 0,0 & 0,0 & 0,3 & 0,0 & 0,7 & 0,30 & 0,37 \\
\hline Other & 1,3 & 0,0 & 17,4 & 5,5 & 1,2 & 4,4 & 1,7 & 5,0 & 3,9 & 4,4 & 11,9 & 6,71 & 5,17 \\
\hline
\end{tabular}


DOI: 10.14807/ijmp.v5i1.80

Table 2: Detailed characterization of selective materials, held in Association of Collectors

\begin{tabular}{lr}
\hline MATERIAL & AMOUNT (\%)/collection (group 2) \\
\hline Reject & 4,29 \\
Newspaper & 10,11 \\
White paper & 12,35 \\
Cardboard & 18,29 \\
Thin plastic & 3,75 \\
Hard plastic & 7,04 \\
PET & 5,15 \\
Glass & 22,48 \\
Ferrous metal & 8,31 \\
Aluminum & 1,29 \\
Copper and related & 0,29 \\
Other & 6,66 \\
\hline \multicolumn{2}{c}{ Source: Maccarini \& Hernández (2007). }
\end{tabular}

Table 3: Detailed characterization from material collected by a collector street, chosen at random

\begin{tabular}{lr}
\hline MATERIAL & AMOUNT (\%) / collection (group 3) \\
\hline Reject & 3,69 \\
Newspaper & 5,13 \\
White paper & 13,98 \\
Cardboard & 34,52 \\
Thin plastic & 2,90 \\
Hard plastic & 5,64 \\
PET & 3,16 \\
Glass & 16,87 \\
Ferrous metal & 4,55 \\
Aluminum & 0,74 \\
Copper and related & 0,17 \\
Other & 8,63 \\
\hline \multicolumn{2}{c}{ Source: Data collected by the author in January 2008}
\end{tabular}

\section{$4 \quad$ RESULTS}

\subsection{Type of waste collected}

The analysis of the percentage of collection by type of waste is shown in Figure 3. In this figure, the mean values appear with intervals LSD (Least Significant Differences Intervals) with 95\% confidence level, confirming the $F$ test significance performed in ANOVA $(F=4.24)$, which shows significant differences $(p=0.0015<$ 
0.005) between some of the percentage of collection by type of waste. Using a Levene's test it was investigated the variance homogeneity which $p$-value $=0.49$, showing there is not a statistically difference amongst the variances at the $95 \%$ confidence level.

The Table 4 shows the multiple comparisons to determine what type of waste has similar percentages, which do not differ significantly at a level of significance of $5 \%$. The method used was the procedure of Least Significant Difference (LSD) of Fischer. The residues, that are in the same group, appear with an " $X$ " in the same column. According the Table 4, may be checked the division of the waste in five groups. Table 5 presents new groupings performed, in order to achieve the mean percentage of each new group, multiplied by the sales per tonne value.

\begin{tabular}{|lccll|}
\hline & Sum of squares & Degree freedom & F-ratio & p-value \\
Between the groups & 1293.1 & 11 & 4.24 & $0.0015(<0.005)$ \\
Within the groups & 664.9 & 24 & & \\
\hline
\end{tabular}

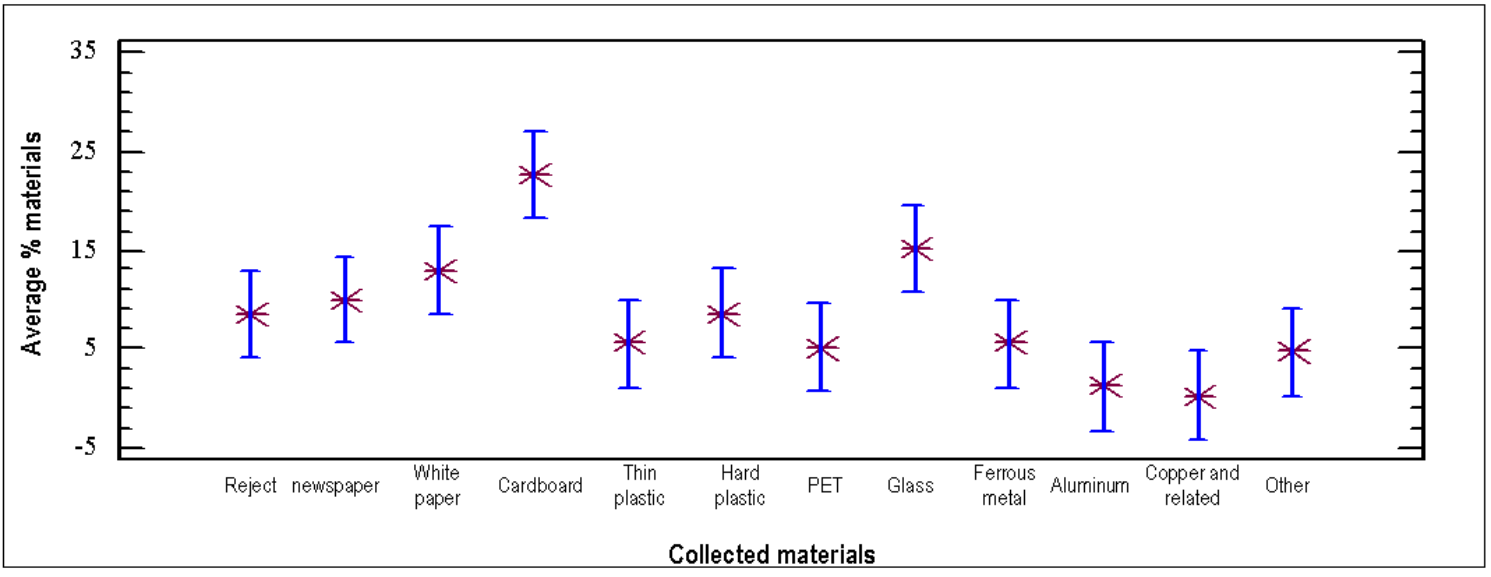

Figure 3: Results of ANOVA and means plot for all analysed recyclables

Table 4: Multiple comparison multiple to determine the affinity between the materials

\begin{tabular}{lllllll}
\hline & Portion (\%) & \multicolumn{3}{l}{ Group } & & \\
\hline & & $\mathbf{1}$ & $\mathbf{2}$ & $\mathbf{3}$ & $\mathbf{4}$ & $\mathbf{5}$ \\
\hline Copper and related & 0,25 & $\mathrm{X}$ & & & & \\
Aluminum & 1,19 & $\mathrm{X}$ & $\mathrm{X}$ & & & \\
Other & 4,60 & $\mathrm{X}$ & $\mathrm{X}$ & $\mathrm{X}$ & & \\
PET & 5,17 & $\mathrm{X}$ & $\mathrm{X}$ & $\mathrm{X}$ & & \\
Ferrous metal & 5,51 & $\mathrm{X}$ & $\mathrm{X}$ & $\mathrm{X}$ & & \\
Thin plastic & 5,54 & $\mathrm{X}$ & $\mathrm{X}$ & $\mathrm{X}$ & & \\
Reject & 8,47 & $\mathrm{X}$ & $\mathrm{X}$ & $\mathrm{X}$ & $\mathrm{X}$ & \\
Hard plastic & 8,59 & $\mathrm{X}$ & $\mathrm{X}$ & $\mathrm{X}$ & $\mathrm{X}$ & \\
Newspaper & 9,97 & & & $\mathrm{X}$ & $\mathrm{X}$ & \\
White paper & 12,93 & & & $\mathrm{X}$ & $\mathrm{X}$ & \\
Glass & 15,14 & & & & $\mathrm{X}$ & $\mathrm{X}$ \\
Cardboard & 22,65 & & & & & $\mathrm{X}$ \\
\hline
\end{tabular}


DOI: 10.14807/ijmp.v5i1.80

Table 5: Analysis and groups formation, without repeating the type of waste

\begin{tabular}{|c|c|c|c|c|c|}
\hline Materials & $\begin{array}{l}\text { Portion } \\
(\%)\end{array}$ & $\begin{array}{l}\text { Total clusters } \\
(\%)\end{array}$ & $\begin{array}{l}\text { Arithmetic mean of } \\
\text { clusters }(\%)\end{array}$ & $\begin{array}{l}\text { Value of sales per } \\
\text { tonne }(R \$)\end{array}$ & $\begin{array}{l}\text { Amount due to } \\
\text { trade }\end{array}$ \\
\hline $\begin{array}{ll}\text { Copper } & \text { and } \\
\text { related }\end{array}$ & 0,25 & 1,44 & 0,72 & $7.000,00$ & $\mathrm{R} \$ 50,41$ \\
\hline Aluminum & 1,19 & & & $2.000,00$ & $\mathrm{R} \$ 14,40$ \\
\hline Other & 4,60 & 47,85 & 7,60 & no set value & $R \$ 0,00$ \\
\hline PET & 5,17 & & & 360,00 & $R \$ 24,61$ \\
\hline Ferrous metal & 5,51 & & & 200,00 & $R \$ 13,67$ \\
\hline Thin plastic & 5,54 & & & 200,00 & $R \$ 13,67$ \\
\hline Reject & 8,47 & & & no set value & $R \$ 0,00$ \\
\hline Hard plastic & 8,59 & & & 260,00 & $\mathrm{R} \$ 17,77$ \\
\hline Newspaper & 9,97 & & & 50,00 & $\mathrm{R} \$ 3,42$ \\
\hline White paper & 12,93 & 28,07 & 18,89 & 400,00 & $R \$ 56,13$ \\
\hline Glass & 15,14 & & & 200,00 & $\mathrm{R} \$ 28,07$ \\
\hline \multirow[t]{2}{*}{ Cardboard } & 22,65 & 22,65 & 22,65 & 180,00 & $\mathrm{R} \$ 40,77$ \\
\hline & & & Total amount due to & the sale of materials & $\mathrm{R} \$ 262,92$ \\
\hline
\end{tabular}

From this survey, the new groups to be formed are:

- First group: copper and similar with aluminium;

- Second group: PET, ferrous metal wastes, hard plastic, thin plastic, newspaper and others;

- Third group: paper and glass;

- Fourth group: cardboard (which got an own group).

For illustrative purposes, the result of materials commercialization per tonne, with previous separation and use of arithmetic average, was $R \$ 234.36$. Using analysis of variance - ANOVA the result was $R \$ 262.92$, similar to the first, which is the real result. In other words, by the mean collection in a ton, the scavenger, using the proposed method, would commercialize the materials with $12.1 \%$ mean difference value between the proposed (ANOVA) and the usual sales, in other words, from actual average (samples), with sorting and weighing each item.

\subsection{Advantages of using the bulk weighing method}

Below are listed some advantages from implementation of bulk weighing method, namely: (i) Due to the time saving in not having to wait to separate the materials, the collectors can return to the section to carry out new collections, (ii) Since the warehouse would be strategically located near the collection site, the travel time would be reduced, because the pickers would not need to move long distances to sell the materials, (iii) If they organize themselves in cooperatives, the values in materials commercialization may be higher, due to wholesale, (iv) If there are values 
DOI: 10.14807/ijmp.v5i1.80

leftovers of trade due to errors in the estimates, these may be divided between them at the end of each month.

\section{CONCLUSIONS}

The study is an initial step for the process optimization and recyclable materials receipt from the bulk weighing. This resulted in the streamlining of materials weighing, and commercialization by scavengers, in other words, is a more efficient and faster way than conventional methods.

ANOVA test $(F-$ ratio $=4.24, p$-value $=0.0015)$ shows the materials that have more differences in the quantities are the cardboard and glass. This means the scavenger could deliver all materials mixed, with the exception of cardboard and glass, then to be weighed and sold without significant losses for both scavenger and receiver.

On the other hand, as recommended by the results of the ANOVA, the recyclable materials should be regrouped into five groups. So can be commercialized in a homogeneous way between each group. This procedure would greatly facilitate the process as a whole because it would not be necessary to separate item by item.

\section{ACKNOWLEDGEMENTS}

We are grateful to CAPES and the Araucaria Foundation for their financial support.

\section{REFERENCES}

ANDRADE, J. B. L. (1989) Avaliação do sistema de limpeza urbana na cidade de Campina Grande. Campina Grande. Thesis (Master) - Engenharia Civil, Universidade Federal da Paraíba.

ASIM, M.; BATOOL, S. A.; CHAUDHRY, M. N. (2012) Scavengers and their role in the recycling of waste in Southwestern Lahore. Resources, Conservation and Recycling, n. 58, p. 152- 162.

AGUNWAMBA, J. C. (2003) Analysis of Scavengers' Activities and Recycling in Some Cities of Nigeria. Environmental Management, v. 32, n.1, p. 116-127.

BATOOL, S. A.; CHAUDHRY, N.; MAJEED, K. (2008) Economic potential of recycling business in Lahore, Pakistan. Waste Management, n. 28, p. 294-298.

BATOOL, S. A.; CHAUDHRY, M. N. (2009) Municipal solid waste management in Lahore City District, Pakistan. Waste Management, n. 29, p. 1971-1981.

BORTOLETO, A. P.; HANAKI, K. (2007) Report: Citizen participation as a part of integrated solid waste management: Porto Alegre case. Waste Manage Res., 25, p.276-282. 
BUENROSTRO, O.; BOCCO, G. (2003) Solid waste management in municipalities in Mexico: goals and perspectives. Resources, Conservation and Recycling, 39, p. 251-263.

CALDERONI, S. (1998) Os bilhões perdidos no lixo. 2.ed. São Paulo, Humanitas Publicações. FFLCH/USP.

CATEN, C. S. (2007) Métodos quantitativos: modo de compatibilidade. Porto Alegre: LOPS - PPGEP - UFRGS. Transparency in Power Point.

CEMPRE. (2007) Compromisso empresarial para a reciclagem. São Paulo. Accessed on October 31, 2007 on page http://www.cempre.org.br.

CEMPRE/EUROSTAT. (2006) Statistical Office of the European Communities. Circular Economy Committee (CEC).

COSTA NETO, P. L. O. (1989) Estatística. São Paulo: Ed. Edgard Blücher.

DAMANHURI, E.; WAHYU, I. M.; RAMANG, R.; PADMI, T. (2009) Evaluation of municipal solid waste $\mathrm{fl}$ ow in the Bandung metropolitan area, Indonesia. J Mater Cycles Waste Manag, n.11, p. 270-276.

DOWNING, D.; CLARK, J. (2000) Business statistics. 2nd ed. New York USA: Barron's Educational Series, Inc.

EIGENHEER, E. (1989) Lixo: morte e ressurreição. In: Associação dos exbolsistas da Alemanha, ed. O lixo como instrumento de resgate social. Compêndio de publicações. Porto Alegre, Instituto GOETHE, p.48-50.

GUTBERLET, J. et al. (2009) Who are our informal recyclers? An inquiry to uncover crisis and potential in Victoria, Canada. Department of Geography, University of Victoria, Victoria, BC, Canada. Set 2009. Accessed November 2009, on page $5 \mathrm{http}: / / \mathrm{dx}$.doi.org/10.1080/13549830903096478.

GUTBERLET, J.; JAYME, B. O. (2010) The Story of My Face: How Environmental Stewards Perceive Stigmatization (Re)produced By Discourse. Sustainability, 2, p. 3339-3353.

HINES, W. W. et al. (2006) Probabilidade e estatística na engennharia. Transl. de Vera Regina Lima de Farias e Flores. $4^{a}$. edição. Rio de Janeiro: LTC.

Jornal Folha de São Paulo.(2006) Brasil já exporta sua tecnologia da miséria urbana. 21/05/2006. Accessed on November 10, 2007, on page http://www1.folha.uol.com.br/fsp/dinheiro.

KIMBUGWE, E.; IBITAYO, O. O. (2013) Analysis of characteristics, activities, and exposure to vermin of human landfill scavengers in a developing nation. Environ Syst. Decis. , in DOI 10.1007/s10669-013-9466-1.

MACCARINI, A. C. (1998) Balanço do potencial energético de resíduos sólidos domiciliares, a partir da coleta seletiva efetuada por catadores. São Carlos. 96p. Thesis (Master) - Escola de Engenharia de São Carlos, Universidade de São Paulo (USP).

MACCARINI, A. C. (2008) Caracterização de material seletivo realizado por catadores. Janeiro.

MACCARINI, A. C.; HERNÁNDEZ, R. H. (2007) Melhoria no processo de triagem de materiais recicláveis a partir da implementação de tecnologias simples. XI 
Seminário Anual de Ensino, Pesquisa e Extensão (SAEPE) XI Jornada de Iniciação Científica (JIC). UTFPR Pato Branco, 02 a 05 de outubro.

MNCR - Movimento Nacional de Catadores de Recicláveis. (2007) O que é o MNCR. São Paulo. Accessed on November 12, 2007 on page http://www.movimentodoscatadores.org.br.

SHIMAZAKI, H. (2007) A method for selecting the bin size of a histogram. Accessed on January 12, 2008, on page http://www.ton.scphys.kyoto-u.ac.jp.

STEVENSON, W. J. (1986) Business statistics: concepts and applications. Cincinnati, Hamilton OH, USA: Harper \& Row Publishers, Inc.

TCHOBANOGLOUS, G. et al. (1993) Integrated solid waste management: engineering principles and management issues. 978p. EUA, McGraw-Hill.

TOLEDO, G. L.; OVALLE, I. I. (1988) Estatística básica. 2a ed. São Paulo: Atlas. 